\title{
HEME SYNTHESIS IN CRITHIDIA DEANEI: INFLUENCE OF THE ENDOSYMBIOTE
}

\author{
Teresa A. Salzman ${ }^{1}$, A. M. del C. Batlle ${ }^{1}$, Jayme Angluster ${ }^{2}$ and Wanderley de Souza ${ }^{3 *}$ \\ ${ }^{\prime}$ Centro de Investigaciones sobre Porfirinas y Porfirias-CIPyP, FCEyN, Universidad de Buenos Aires, \\ Ciudad Universitaria, Pabellón II, 1428 Buenos Aires, Argentina \\ 2Instituto de Microbiologia, UFRJ, Ilha do Fundão, Rio de Janeiro, Brasil \\ ${ }^{3}$ Instituto de Biofísica. UFRJ, Ilha do Fundão, 21941 Rio de Janeiro, Brasil
}

(Received 22 Mav 1985)

\begin{abstract}
The activity of the following enzymes involved in the biosynthesis of porphyrins was determined in endosymbiote-free and endosymbiote-containing Crithidia deanei grown in a chemically defined medium: succinyl Coenzyme A synthetase (Suc.CoA-S), 5-aminolevulinate synthetase (ALA-S), 4,5-dioxovaleric acid transaminase (DOVA-T), S-aminolevulinate dehydratase (ALA-D), porphobilinogenase (PBGase), deaminase and heme synthetase (Heme-S). The amount of 5-aminolevulinic acid (ALA) and porphobilinogen, porphyrins and heme was also determined.

2. ALA and PBG were detected in $C$, deanei. The levels of free porphyrins was low. Heme concentration was nil.

3. The activity of ALA-D, deaminase and PBGase was not detected in $C$. deanei.

4. The activity of Suc.COA-S and ALA-S were twice higher in symbiote-containing than in aposymbiotic $C$. deanei. Aposymbiotic cells had a higher activity of DOVA-T than symbiote-containing cells.

5. The level of Heme-S, measured using protoporphyrin as substrate, was twice as high in symbiotecontaining than in symbiote-free cells.
\end{abstract}

\section{INTRODUCTION}

Crithidia deanei, a flagellated trypanosomatid protozoan, isolated from the hemipteran Zelus leucogramus and harboring endosymbiote (Mundim et al., 1974) was made aposymbiotic with high doses of chloramphenicol (Mundim and Roitman, 1977). A chemically defined medium supports growth of both normal and aposymbiotic strains (Roitman et al., 1972). Such intracellular symbiotes are integrated into the physiology of the host cell (McGhee and Cosgrove, 1980). It was shown that the presence of the endosymbiote influenced significantly the composition of carbohydrates exposed on the cell membrane and slightly the surface anionic groups of C. deanei (Oda et al., 1984).

Nutritional studies carried out in flagellate trypanosomatids have clearly demonstrated that heme compounds, including hemin, hematin or hemoglobin, are essential growth factors (Lwoff, 1951). Possibly such nutritional requirements are associated with their inability for heme biosynthesis (Roitman et al., 1972; Chang and Sassa. 1975). Trypanosomatids

*Author to whom correspondence should be addressed. Abbreviations: ALA, 5-aminolevulinic acid; ALA-D, 5-aminolevulinate dehydratase; ALA-S, 5-aminolevulinate synthetase; ATP, adenosin triphosphate; CoA, Coenzyme A; Coprogen III, coproporphyrinogen III; CPGase, coproporphyrinogenase; DOVA, 4,5-dioxovaleric acid; DOVA-T, L-alanine-4,5-dioxovaleric; acid aminotransferase; Heme-S, heme synthetase; $\mathrm{PBG}$, porphobilinogen; PBGase, porphobilinogenase; Proto, protoporphyrin; Protogen IX, protoporphyrinogen IX; Ppgen-ox, protoporphyrinogen oxidase; Suc.CoA-S succinyl Coenzyme A synthetase; Urogen, uroporphyrinogen; Urogen.Dec.ase, uroporphyrinogen decarboxylase such as Blastocrithidia culicis, Crithidia oncopelti and $C$. deanei-hearing symbiote do not require heme substances for growth (Mundim and Roitman, 1977; Chang and Sassa, 1975). Presumably the bacterial symbiotes supply the host trypanosomatids with heme biosynthetic capability (Chang and Sassa, 1975). However, how the presence of symbiote may regulate the enzyme activities in the flagellate heme biosynthetic pathway is not completely understood.

Taking into account the currently accepted porphyrin pathway (Fig. 1), we have investigated several enzymic activities in the heme biosynthetic chain in symbiote-bearing and symbiote-free strains of $C$. deanei. The results obtained in $C$. deanei suggest that the presence of the endosymbiote increases the activity of some enzymes and early porphyrin precursors of the heme biosynthetic pathway.

\section{MATERIALS AND METHODS}

\section{Microorganism}

Symbiote-bearing Crithidia deanei (ATCC 30255) was maintained by weekly transfers in a chemically defined medium (Roitman et al., 1972), without hemin, distributed in 5-ml volumes in screw-capped tubes. The aposymbiotic strain required nicotinamide $(3 \mathrm{mg} \%)$ and hemin $(1 \mu \mathrm{g} \%)$ which was added to the same defined medium.

For the experiments, cells were grown in 31. flasks containing $1.5 \mathrm{l}$. of the defined medium referred to above. The medium was autoclaved at $120 \mathrm{C}$ for $20 \mathrm{~min}$. The inoculum consisted of $30 \mathrm{ml}$ of $48-\mathrm{hr}$ culture; about $6 \times 10^{7}$ cells were inoculated per flask. After $48 \mathrm{hr}$ of incubation the cells were collected by centrifugation $(2000 \mathrm{~g}$ for $10 \mathrm{~min})$ at $4 \mathrm{C}$ and were washed 2 times in cold $25 \mathrm{mM}$ Tris- $\mathrm{HCl}$ buffer. $250 \mathrm{mM}$ sucrose, $5 \mathrm{mM} \mathrm{KCl}, \mathrm{pH} 7.0$; glass powder $(5 \mathrm{~g} / \mathrm{g}$ cells, wet weight) was added to the washed pellet, and the mixture was ground in a mortar for 5 min at $4 \mathrm{C}$. This procedure resulted in a complete breakage of the cells, as 

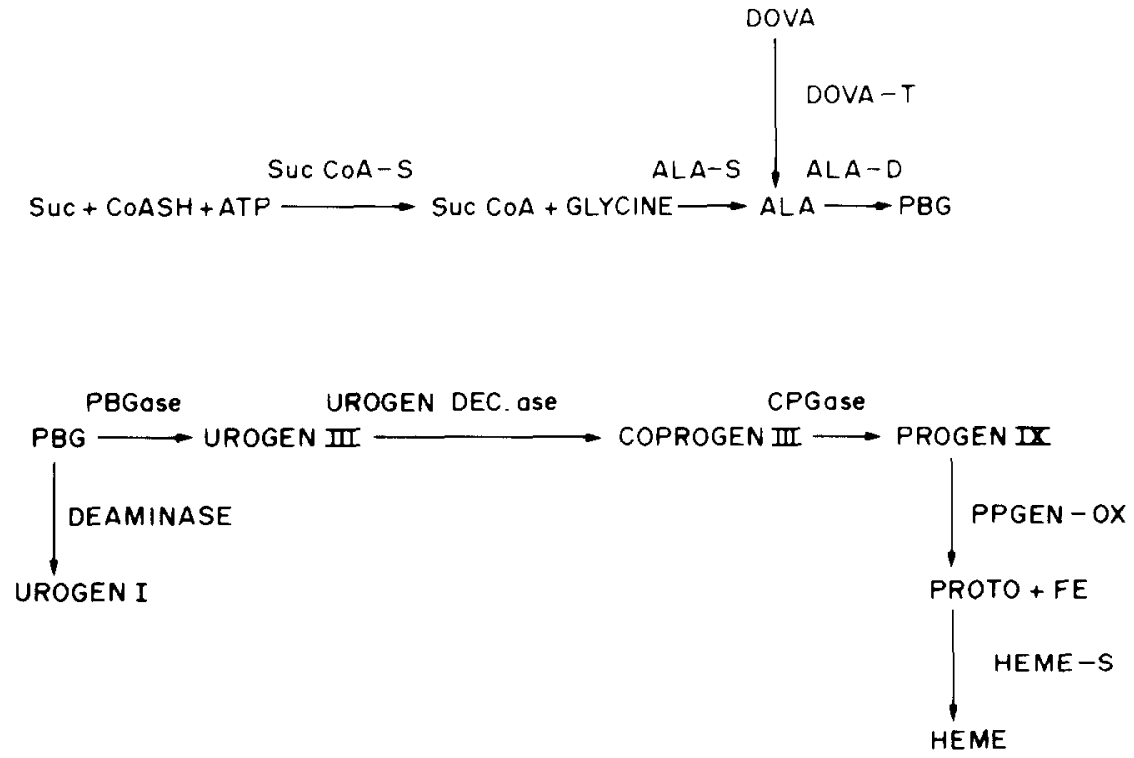

Fig. 1. Porphyrin pathway.

revealed by phase contrast microscopy. Most of the glass powder was separated by decantation. The disrupted cells were then suspended in either $25-50 \mathrm{mM}$ Tris- $\mathrm{HCl}$ buffer or $25-50 \mathrm{mM}$ phosphate buffer (approximately $10 \mathrm{ml} / \mathrm{g}$ cells, wet weight) at the $\mathrm{pH}$ indicated depending on the enzyme under study. The suspension was centrifuged at $580 \mathrm{~g}$ for $10 \mathrm{~min}$, the precipitate discarded and the supernatant employed for measuring enzymic activities.

\section{Chemicals}

PBG, protoporphyrin IX. mesoporphyrin IX and deuteroporphyrin IX were obtained from Burnham, Porphyrin Products, Utah, U.S.A. CoA, ATP, ALA and succinate were purchased from Sigma Chem. Co., St Louis, Missouri. U.S.A. DOVA, was prepared following the procedure of Dörnermann and Senger (1980). All other reagents were of AR grade of the highest purity obtained from scveral commercial sources.

Extraction and determination of precursors and porphyrins

$A L A$ and PBG. A $3.2 \mathrm{ml}$ sample of the $580 \mathrm{~g}$ supernatant was treated with $0.32 \mathrm{ml}$ of $50 \%$ TCA. The protein precipitate was separated by centrifugation and ALA and PBG measured in the supernatant according to Mauzerall and Granick (1956).

Porphyrins. These were determined according to the procedure described by Salzman et al. (1982).

\section{Determination of free-heme}

A calibration curve was obtained following the method described by Porra and Jones (1963). Hemin was measured by the same procedure in the $580 \mathrm{~g}$ supernatant of C. deamei.

\section{Assay of enzymic activitios}

Succinyl CoA Slntherase (Suc.CoA-S) was determined in the supernatant of $C$. deanei in $0.025 \mathrm{M}$ Tris $\mathrm{HCl}$ buffer, $\mathrm{pH}$ 7.4 , according to the procedure described by Wider de Xifra and Tigier (1970) with slight modifications.

5-Aminolevulinate symthetase $(A L A-S)$ was assayed in the supernatant in $0.025 \mathrm{M}$ Tris- $\mathrm{HCl}$ buffer. $\mathrm{pH}$ 7.4. as described by Wider de Xifra et al. (1971).

4,5-Dioxovaleric acid-transaminase (DOVA-T). The ability of $C$. deanei to catalyze the conversion into ALA was assayed by incubation of the supernatant in $0.1 \mathrm{M} \mathrm{Na}$ phosphate buffer, $\mathrm{pH} 7.5$. containing $5 \mathrm{mM}$ DOVA. $20 \mathrm{mM}$
$\mathrm{L}$-alanine (final vol $\mathrm{I} \mathrm{ml}$ ). Samples were incubated anaerobically with gentle agitation at $37 \mathrm{C}$ in the presence of light $(2500 \mathrm{~lx})$. The reaction was stopped by addition of $1 \mathrm{ml}$ of $10 \%$ TCA. ALA synthesized was assayed in the supernatant according to Mauzerall and Granick (1956) and the remaining DOVA following the method of Milligan and Baldwin (1967).

5-Aminolevulinate dehydratase $(A L A-D)$. This was assayed in the supernatant in $0.05 \mathrm{M}$. Tris- $\mathrm{HCl}$ buffer $(\mathrm{pH}$ 7.4) following: (a) the procedure described by Tigier et al. (1970); (b) ALA-D activity was also measured using the same incubation mixture as in (a) but adding $1.08 \mathrm{mM}$ $\mathrm{ZnSO}_{4}$ (Brocklehurst et al., 1980).

Porphohilinogenase (PBGase) and deaminase $(D)$. The trivial name PBGase was used to designate the two enzyme system of PBG deaminase uroporphyrinogen III cosynthetase (or simply deaminase isomerase). PBGase and deaminase were estimated in $0.046 \mathrm{M}$ Tris HCL buffer (pH 7.4) according to Batle 't al. (1978).

Heme-synthetase (Heme-S). The method of Porra and Jones (1963) was followed with slight modifications. The supernatant, in $0.05 \mathrm{M} \mathrm{K}$ phosphate buffer $(\mathrm{pH} \mathrm{8.0)}$, was preincubated at $37 \mathrm{C}$ in anaerobiosis in Thunberg tubes with porphyrin substrate $(37 \mu \mathrm{M}$ protoporphyrin IX. $35 \mu \mathrm{M}$ mesoporphyrín IX, $32 \mu \mathrm{M}$ deuteroporphyrin IX). The reaction was started by tipping $40 \mu \mathrm{mol}$ of dithiotreitol (DTT), $400 \mu \mathrm{mol}$ of $\mathrm{FeSO}_{4}$ from the side arm of the tube and further incubated for $\mathrm{I} \mathrm{hr}$ with constant shaking. The final volume was $4.2 \mathrm{ml}$. The reaction was stopped by opening the tube and adding $1.0 \mathrm{ml}$ of pyridine. then $0.5 \mathrm{ml}$ of $1 \mathrm{~N} \mathrm{NaOH}$ and $1.0 \mathrm{ml}$ of iodoacetamide. The resulting mixture was equally divided between two cuvettes: $2 \mathrm{mg}$ of solid $\mathrm{Na}_{2} \mathrm{~S}_{2} \mathrm{O}_{4}$ was added to one cuvette and $0.05 \mathrm{ml}$ of $3 \mathrm{mM} \mathrm{K} 3 \mathrm{Fe}(\mathrm{CN})_{6}$ to the other. Heme formed was calculated using the equation of Porra and Jones (1963).

\section{Enzyme units}

One unit of enzyme activity was defined as the amount of enzyme which catalyzes the formation of $1 \mathrm{nmol}$ of product and or the consumption of $1 \mathrm{nmol}$ of substrate in $60 \mathrm{~min}$ under the standard incubation conditions. Enzyme activities are expressed as units per mg protein (specific activity) Determination of proteins, was done using the method of Lowry el al. (1951). 


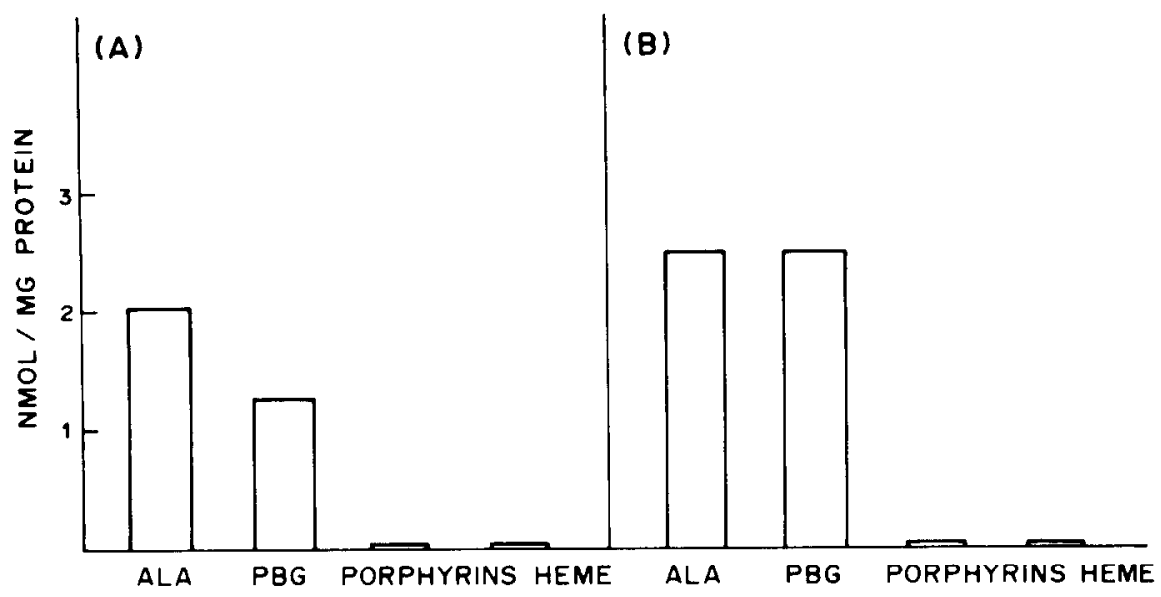

Fig. 2. Content of 5-aminolevulinic acid (ALA), porphyrins, porphobilinogen (PBG), porphyrins and heme in symbiote-free (A) or symbiote-containing (B) Crithidia deanei.

\section{RESULTS}

As shown in Fig. 2 ALA and PBG were detected in both symbiote-containing and symbiote-free $C$. deanei. However, these porphyrin precursors were increased in symbiote-containing flagellates. The levels of free porphyrins was very low. Heme concentration was nil.

The activities of Suc.CoA-S, ALA-S, DOVA, ALA-D, PBGase, deaminase and Heme-S activities are shown in Fig. 3. The Suc.CoA-S activity was more than twice higher in the symbiote-containing than in the symbiote-free flagellates. Similar results were observed with the ALA-S activity. The level of ALA-D was very low: this enzyme activity was not markedly altered even in the presence of $\mathrm{Zn}^{2+}$ ions, a known activator of this enzyme. Also, in both strains of $C$. deanei the PBGase activity was negligible whereas some functionality was detected in the symbiote-free strain, when evaluated by the PBG consumed. A similar pattern was observed with deaminase activity, but the enzyme functionality, measured as PBG consumed, was increased in the symbiote-containing $C$. deanei as compared with symbiote-free cells. Heme-S was active in $C$. deanei cells as evaluated by meso and protoheme formed. However, in the later case the enzyme activity was markedly increased in the symbiote-bearing flagellates. When the enzyme activity was measured as deuteroheme formed a certain Heme-S functionality was detected only in the symbiote-free cells.

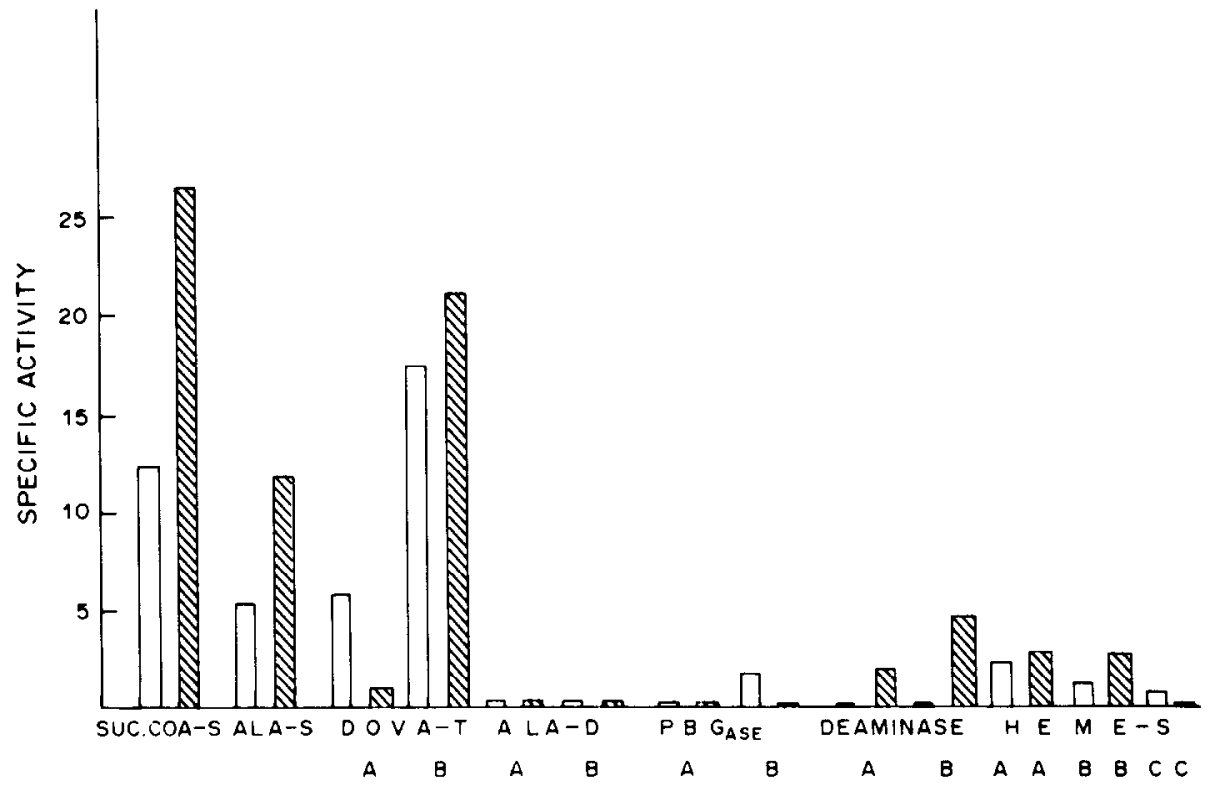

Fig. 3. Specific activity of enzymes involved in the heme pathway in symbiote-free $(\square)$ or symbiotecontaining ( $\square$ ) Crithidia deanei. In the case of DOVA-T, A corresponds to ALA formed and B to DOVA consumed. In the case of ALA-D, $\mathrm{Zn}^{2+}$ was present $(B)$ or not (A) in the incuhation medium. In the case of PBGase and deaminase (A) corresponds to porphyrin formed and (B) to PBG consumed. In the case of Heme-S, (A), (B) and (C) corresponds to mesoheme, protoheme and deuteroheme formed, respectively. 


\section{DISCUSSION}

Requirement of $C$. deanei for heme (Mundim et al., 1974) is the same as that found in other endosymbiote-free insect flagellates (Hutner et al., 1979). This requirement, also observed in Ricketsia (Myers et al., 1972), bacteria (Lascelles, 1962) and possibly some obligate blood sucking insects (Lwotf, 1951), indicates a metabolic lesion in such organisms of the heme biosynthetic chain. However, growth of $C$. deani (Mundim et al., 1974), (. oncolpeti and Blastocrithidia culicis (Chang and Sassa, 1975) harboring endosymbiotic bacterium-like organisms in a hemin-free medium suggests that the endosymbiotes contribute to the host flagellate with heme biosynthetic capability. In the present work we demonstrate that the bacterial symbiotes increase the activity of several enzymes associated with the heme biosynthetic pathway of $C$. deanei.

Extracts of both symbiote-free and symbiotecontaining $C$. deanei showed the presence of ALA and $\mathrm{PBG}$. However, in symbiote-bearing flagellates the concentration of ALA and PBG was markedly increased. Since both porphyrin precursors are not components of culture medium they were synthesized by the cells. Previous nutritional studies revealed that Leishmania tarentolae (Gaugham and Krassner, 1971), B. culicis and C. oncolpelti (Chang and Sassa, 1975) are unable to utilize ALA and PBG. In addition it was demonstrated that at least radioactive ALA enter readily into hemoflagellates (Gaugham and Krassner, 1971). These nutritional studies, the low amount of porphyrins and nil heme concentrations observed in the present work and previously in $T$. cruzi (Salzman et al., 1982) and the results reported in both symbiote-containing and symbiotefree trypanosomatids (Chang and Sassa, 1975) suggest that hemoflagellates may be in general incapable of adequate tetrapyrrole pathway biosynthesis.

It is well established that succinyl CoA participates in the committed step of porphyrin biosynthesis in animals and bacteria: its condensation with glycine produces aminolevulinic acid (ALA). Therefore Suc.CoA-S can be involved in the tetrapyrrole pathway (Batle et al., 1975. The Suc.CoA-S activity was significantly higher in the symbiote-containing $C$. deanei as compared with symbiote-free flagellates. A similar finding has been reported earlier with $B$. culicis and $C$. oncopelti: the rate of incorporation of carbon from glycine was greater for symbiotecontaining trypanosomatids than for those without symbiotes (Chang and Sassa, 1975).

Two routes for ALA formation have been proved to exist together in the same cell: the direct synthesis of ALA. catalyzed by ALA-synthetase (ALA-S) (Kikuchi et al., 1958) and the so called 5-carbon pathway (Beale, 1978) where ALA may be formed via DOVA-transaminase (DOVA-T). Both ALA pathways were looked for. L-Alanine-4,5-dioxovaleric acid transaminase (DOVA-T) utilizes L-alanine as the amino donor and 4,5-dioxovaleric acid as the amino acceptor (Varticovski et al. 1980). The reaction products are ALA and pyruvate. The study of DOVA-T has revealed that the activity of this enzyme is nearly six times higher in the symbiote-free C. deanei cells. when the activity was expressed as a function of ALA formed. In contrast, the DOVA-T activity was highest in $C$. deane $i$ when evaluated by the amount of DOVA consumed. However, it is known that DOVA might be metabolized via other routes and in this case only the amount converted to ALA could be relevant. ALA-S, which catalyzes the condensation of Suc.CoA with glycine with the production of ALA, the first product of the biosynthetic chain of heme, was significantly higher in the symbiote-containing strain than in the symbiote-frec cells. Therefore, we concluded that in $C$. deanei harboring endosymbiote ALA is synthesized via ALA-S, while in the symbiote-free cells its synthesis occurs via DOVA-T, thus once indicating the contribution of the bacterial symbiote for the heme biosynthetic pathway. ALA-S was equally active in strains of Euglena gracilis (Beale et al., 1981) and in T. cruzi (Salzman et al., 1982).

5-Aminolevulinic acid dehydratase (ALA-D) catalyzes the condensation of 5-aminolevulinic acid into porphobilinogen (PBG). As previously observed in $T$. cruzi (Salzman et al., 1982), it was also difficult to detect ALA-D activity in $C$. deanei extracts in either the symbiote-containing or symbiote-free cells under the optimal conditions: its level was almost negligible. The enzyme was also measured by supplementing the incubation mixture with a known activator such as $\mathrm{Zn}^{2+}$ ions (Brocklehurst et al., 1980). Nevertheless the enzyme activity did not increase markedly in any of the extracts under study.

The PBGase and deaminase activities could not be detected either in the symbiote-bearing or the symbiote-free $C$. deanei. However the specific activity of uroporphyrinogen I synthetase (deaminase) was increased in symbiote-containing flagellates (Chang and Sassa, 1975). Such different results may be attributed to the use of different trypanosomatids. In $T$. cruzi PBGase and deaminase activities were also absent or inactive (Salzman et al., 1982).

Heme-synthetase (Heme-S) catalyzes the addition of iron to different porphyrins, and particularly to protoporphyrin, in the formation of heme. This enzyme has a specific requirement for $\mathrm{Fe}^{2}+$ but not for the porphyrin substrate; either meso or deuteroporphyrins may function as substrates but, in the cell, only protoporphyrin would be available. In our experiments the activity was always measured by using proto, meso and deuteroporphyrin as substrate. There could not be detected an actual difference in the Heme-S activity of both strains of $C$. deane $i$ when mesoporphyrin was the substrate. When the activity was cxpressed as the amount of deuteroheme formed only the symbiote-free strain showed a certain functionality. However, the level of Heme-S activity, measured with protoporphyrin as substrate. was significantly higher in the symbiote-containing cells suggesting that the bacterial symbiotes endow the host flagellates with an adequate heme biosynthetic capability. Heme-S was fully active in $T$. cruzi (Salzman et al., 1982). B. culicis and (. oncopelti (Chang and Sassa, 1975), whereas in some strains of Haemophylus influenzae, Staphylococcus aureus va 571 (Jensen and Thofern, 1953) and L. tarentolac (Gaugham and Krassner, 1971) Heme-S is apparently lacking.

It is interesting that in $C$. deanei the activity of the 
enzymes usually confined to the cytosol of most cells including ALA-D, PBGase and deaminase is low, while that of the particulate enzymes such as Suc.CoA, ALA-S, DOVA-T and heme synthetase is readily detectable. A comparable finding was previously noted in T. cruzi (Salzman et al., 1982). These results would suggest that Trypanosomatidae have lost part of their heme biosynthetic ability.

In conclusion, the fact that $C$. deanei harboring endosymbiote does not require hemin in its culture medium, suggest that the presence of the bacterial endosymbiote increases a certain limited heme biosynthetic capacity in the flagellates supplying them with certain enzymes and early porphyrin precursors of this pathway. Also, the present work confirms, as suggested earlier (Esteves et al., 1982), that $C$. deanei is an excellent experimental model for study of the symbiote-host interactions.

Acknowledgements - This work has been supported by the UNDP/World Bank/WHO Special Programme for Research and Training in Tropical Diseases, Conselho Nacional de Desenvolvimento Científico e Tecnológico (CNP4) and Financiadora de Estudos e Projetos (FINEP). AMCB holds the post of Principal Scientific Researcher in the Argentina Research Council (CONICET).

\section{REFERENCES}

Batlle A. M. del C., Llambias E. B. C., Wider de Xifra E. and Tigier H. A. (1975) Porphyrin biosynthesis in the soybean callus tissue system. XV. The effect of growth conditions. Int. J. Biochem. 6, 591-606.

Batlle A. M. del C., Wider de Xifra E. A. and Stella A. M. (1978) A simple method for measuring erythrocyte porphobilinogenase and its use in the diagnosis of acute intermittent porphyria. Int. J. Biochem. 9, $871-876$.

Beale S. I. (1978) 5-Aminolevulinic acid in plants: its biosynthesis, regulation and role in plastid development. A. Rev. Plant Physiol. 29, 95-120.

Beale S. 1., Foley T. and Dzelzkalns V. (1981) 5-Aminolevulinic acid synthetase from Euglena gracilis. Proc. natn. Acad. Sci. U.S.A. 78, 1666-1669.

Brocklehurst D., Wider de Xifra E. H. and Batlle A. M. del C. (1980) The measurement of erythrocyte uroporphyrinogen I synthetase in the diagnosis of latent and acute intermittent porphyria. Int. J. Biochem. 12, 791793.

Chang K. P. and Sassa S. (1975) Heme biosynthesis in bacterium-protozoon symbiosis: enzymic defects in host hemoflagellates and complemental role of their intracellular symbiotes. Proc natn. Acad. Sci. U.S.A. 72, 2979-2983.

Dörnermann D. and Senger H. (1980) The synthesis and properties of 4,5-dioxovaleric acid, a possible intermediate in the biosynthesis of 5-aminolevulinic acid, and its in vivo formation in Scenedesmus obliquos. Biochim. biophys. Acta 628, 35-45.

Esteves M. J. G., Andrade A. F. B., Angluster J., De Souza W., Mundim M. H., Roitman I. and Pereira M. E. A. (1982) Cell surface carbohydrates in Crithidia deanei: influence of the endosymbiote. Eur. J. Cell Biol. 26, 244. 248.

Gaugham P. L. Z. and Krassner S. H. (1971) Hemin deprivation in culture stages of the hemoflagellate Leish mania tarentolae. Comp. Biochem. Physiol. 39B, 5-18.

Hutner S. H., Bacchi C. J. and Baker H. (1979) Nutrition of the kinetoplastida. In Biology of the Kinetoplastida (Edited by Lumsden W. H. R. and Evans D. A.), Vol. 2, pp. 654-691. Academic Press, New York.

Jensen J and Thofern E. (1953) Chloramin (ferroporphyrin chloride) als Bakterienurichsstoff. Naturforsch. 86, 599-607.

Kikuchi G., Kumar A., Talmadge P. and Shemin D. (1958) The enzymic synthesis of 5-aminolevulinic acid. J. hiol. Chem. 233, 1214-1219.

Lascelles J. (1962) Tetrapyrrole synthesis in microorganisms. In The Bacteria (Edited by Gunsalus I. C. and Stanier R. Y.), Vol. 3. pp. 335 372. Academic Press, New York.

Lowry O. H., Rosebrough N. J., Farr A. L. and Randall R. J. (1951) Protein measurement with the Folin phenol reagent. J. biol. Chem. 193, 581.590.

Lwoff M. (1951) The nutrition of parasitic flagellates (Trypanosomidae, Trichomonadinae). In Biochemistry and Physiology of Protozoa (Edited by Lwoff A.), pp. 131 182. Academic Press, New York.

Mauzerall $M$. and Granick S. (1956) The occurrence and determination of ALA and $\mathrm{PBG}$ in urine. $J$. hiol. Chem. 219, 435 .

McGhee R. B. and Cosgrove W. B. (1980) Biology and physiology of the lower Trypanosomatidae. Microbiol. Ret. 44, 140-173.

Milligan L. P. and Baldwin R. L. (1967) The conversion of acetoacetate to pyruvaldehyde. $J$. hiol. Chem. 242 , 1095-1101.

Mundim M. H. and Roitman I. (1977) Extra nutritional requirements of artificially aposymbiotic Crithidia deanei. J. Protozool. 24, 329-331.

Mundim M. H., Roitman I., Herman M. A. and Kitajima W. E. (1974) Simples nutrition of Crithidia deanei, a reduvid trypanosomatid with endosymbiote. J. Protozool. 21, 518-521.

Myers W. F., Osterman J. V. and Wisseman C. L. (1972) Nutritional studies of Rickettsia quintana: nature of the hematin requirement. J. Bacteriol. 109, 89-95.

Oda L. M., Alviano C. S., Silva Filho F. C., Angluster J., Roitman I. and De Souza W. (1984) Surface anionic groups in symbiote-bearing and symbiote-free strains of Crithidia deanei. J. Protozool. 31, 131 134.

Porra R. J. and Jones O. T. G. (1963) Studies on ferrochelatase I. Assay and properties of ferrochelatase from a pig liver mitochondrial extract. Biochem. $J .87,181185$.

Roitman C., Roitman I. and Azevedo H. P. (1972) Growth of an insect trypanosomatid at $37 \mathrm{C}$ in a defined medium. J. Protozool. 19, 346-349.

Salzman T. A., Stella A. M.. Wider de Xifra E. A., Batlle A. M. del C., Docampo R. and Stoppani A. O. M. (1982) Porphyrin biosynthesis in parasitic hemofagellates functional and defective enzymes in Trypanosoma cruzi. Comp. Biochem. Phrsiol. 72B(4), 663-667.

Tigier H. A., Batlle A. M. del C. and Locascio G. (1970) Porphyrin biosynthesis in soybean callus tissues. III. Improved purification and some properties of 5-aminolevulinate dehydratase. Enzymology 38, 43-56.

Varticovski L., Kushner J. P. and Burnham B. F. (1980) Biosynthesis of porphyrim precursors: purification and characterization of L-alanine: 4,5-dioxovaleric acid aminotransferase. $J$. hiol. Chem. 255, $3742 \cdot 3747$.

Wider de Xifra E. A. and Tigier H. A. (1970) Properties and regulatory effect on terapyrrole biosynthesis of succinyl CoA synthetase isolated from soy bean callus tissues system. FEBS Lett. 9, 30-32.

Wider de Xifra E. A., Battle A. M. del C. and Tigier H. A (1971) Delta aminolevulinate synthetase in extracts of cultured soybean cells. Biochim. hiophis. Acts. 235 , $511-517$. 